\title{
Dysregulated function of normal human epidermal keratinocytes in the absence of filaggrin
}

\author{
NINGNING DANG ${ }^{1,2}$, XIAOLI MA ${ }^{3}$, XIANGUANG MENG ${ }^{1}$, LIGUO AN $^{2}$ and SHUGUANG PANG ${ }^{4}$ \\ ${ }^{1}$ Department of Dermatology, Jinan Central Hospital Affiliated to Shandong University, Jinan, Shandong 250013; \\ ${ }^{2}$ College of Life Science, Shandong Normal University, Jinan, Shandong 250014; ${ }^{3}$ Central Laboratory; \\ ${ }^{4}$ Department of Endocrinology, Jinan Central Hospital Affiliated to Shandong University, Jinan, Shandong 250013, P.R. China
}

Received September 12, 2015; Accepted June 21, 2016

DOI: $10.3892 / \mathrm{mmr} .2016 .5539$

\begin{abstract}
The aim of the present study was to investigate the impact of filaggrin knockdown on the function of normal human epidermal keratinocytes (NHEKs). Filaggrin expression levels in NHEKs were knocked down by lentivirus (LV) encoding small hairpin RNA (shRNA), with control cells infected with nonsense shRNA or not infected. Cell migration and invasion were assayed using Transwell inserts, cell adhesion and proliferation by the Cell Counting kit- 8 assay, and apoptosis and cell cycle progression by flow cytometry. shRNA efficiently suppressed expression of filaggrin protein. The LV group had significantly decreased cell migration, adhesion and proliferation, and increased apoptosis compared with the control groups $(\mathrm{P}=0.027)$. In addition, the proportion of cells in $G_{1}$ and $G_{2}$ phases were significantly increased in the LV group compared with control groups $(\mathrm{P}=0.018)$. The results of the present study demonstrate that filaggrin knockdown inhibits NHEK migration, adhesion and proliferation, promotes apoptosis and disturbs cell cycle progression.
\end{abstract}

\section{Introduction}

The FLG gene, which encodes filament aggregating protein (filaggrin), is located on human chromosome 1q21 (1). Filaggrin is a filament-associated protein that binds to keratin fibers in epithelial cells. Filaggrin monomers cluster into profilaggrin, which is processed into filaggrin monomers by proteolysis. Filaggrin is crucial for epidermal homeostasis and contributes to the construction of the lipid envelope, which is critical for skin barrier function (2). It is a critical component of the stratum corneum, which provides primary protection in

Correspondence to: Dr Shuguang Pang, Department of Endocrinology, Jinan Central Hospital Affiliated to Shandong University, 105 Jiefang Road, Jinan, Shandong 250013, P.R. China

E-mail: shuguangpang@163.com

Key words: atopic dermatitis, apoptosis, cell migration, filaggrin knockdown, normal human epidermal keratinocytes, signaling pathways humans due to its physical strength, hydration status, skin $\mathrm{pH}$ and buffering capacity (3).

The importance of filaggrin in the frontline skin barrier (4) is demonstrated by the predisposition of individuals with filaggrin mutations to various conditions, including dry skin, ichthyosis and atopic dermatitis (5-7). Thus, it is necessary to fully understand the functions of filaggrin to facilitate the treatment of these diseases. It has been demonstrated that filaggrin expression in keratinocytes results in decreased proliferation, post- $G_{1}$ phase arrest and loss of cell-cell adhesion (8). In addition, filaggrin increases the susceptibility of keratinocytes to apoptosis in response to apoptosis-inducing stimuli (9). Furthermore, there is evidence to suggest that filaggrin contributes to nuclear events associated with apoptosis of epidermal keratinocytes (10). However, the effect of filaggrin knockdown on the functions of normal human epidermal keratinocytes (NHEKs) remains to be fully elucidated.

In the present study, the effect of filaggrin absence on migration, invasion, adhesion, proliferation, apoptosis and cell cycle progression in NHEKs was investigated. The results of the present study may facilitate the determination of the pathogenesis of filaggrin mutation-associated disorders.

\section{Materials and methods}

Cell culture. NHEKs were purchased from Invitrogen; Thermo Fisher Scientific, Inc. (Waltham, MA, USA), and cultured in EpiLife ${ }^{\circledR}$ medium supplemented with growth factors (Invitrogen; Thermo Fisher Scientific, Inc.). Cells were cultured in $10 \mathrm{~cm}$ dishes in a $5 \% \mathrm{CO}_{2}$ incubator at $37^{\circ} \mathrm{C}$. The medium was replaced every second day and the cells were split 1:2 every 3 days. For experiments other than cell proliferation and adhesion, cells were cultured with $1.5 \mathrm{mM}$ calcium for $24 \mathrm{~h}$ to induce differentiation.

Filaggrin silencing by LV infection. The present study used the following LV-encoding shRNA infection to knockdown filaggrin: GTTGGCTCAAGCA TATTATTT (position: nt-274). The negative control (NC) shRNA sequence was CAACAAGATGAAGAGCACC. The complementary DNA of the shRNA was inserted into the LV gene transfer vector and the double stranded shRNA oligo was cloned into pGLV-H1-GFP (Shanghai GenePharma Co., Ltd., Shanghai, 
China) with BamHI and EcoRI (Thermo Fisher Scientific, Inc.). The construct was validated by western blotting. The shRNA-infected cells were referred to as the LV group, cells infected with control non-filaggrin shRNA as the NC group, and cells without infection as the blank group.

The constructs were diluted 1:4 with EpiLife ${ }^{\circledR}$ medium containing $10 \%$ fetal calf serum (FCS; Invitrogen; Thermo Fisher Scientific, Inc.) and $10 \mathrm{mg} / \mathrm{ml}$ polybrene ${ }^{\circledR}$ (Santa Cruz Biotechnology, Inc., Dallas, TX, USA), to a final concentration of $5 \mu \mathrm{g} / \mathrm{ml}$; this was the LV working solution. When the NHEKs reached $90 \%$ confluence, the cells were digested using $1 \mathrm{ml} 0.25 \%$ trypsin-ethylenediaminetetraacetic acid (EDTA) solution, and single cell suspensions were prepared. Cells were seeded into 6 -well plates $\left(1 \times 10^{6}\right.$ cells/well) and incubated in EpiLife ${ }^{\circledR}$ medium containing $10 \%$ FCS at $37^{\circ} \mathrm{C}$ and $5 \% \mathrm{CO}_{2}$ for $24 \mathrm{~h}$. Following this, the EpiLife ${ }^{\circledR}$ medium was removed and $1 \mathrm{ml} \mathrm{LV}$ working solution was added to each experimental well and incubated for $24 \mathrm{~h}$. Cells were observed under a fluorescence microscope (Olympus America, Inc., Melville, NY, USA). The results of the preliminary experiments revealed that LV was stably expressed for four days.

Migrationassays.Cellmigration was analyzed using Transwell inserts with an $8-\mu \mathrm{m}$ pore membrane (BD Biosciences, San Jose, CA, USA) as described previously $(11,12)$. The LV-infected cells were grown to sub-confluence $(75-80 \%)$ and then serum-starved for $24 \mathrm{~h}$. Following detachment with trypsin, the cells were washed with phosphate-buffered saline (PBS) and resuspended in serum-free medium. Subsequently, $100 \mu 1$ cell suspension $\left(3 \times 10^{5}\right.$ cells $\left./ \mathrm{ml}\right)$ was added to the upper chamber. The membranes were coated with $0.01 \%$ collagen type I in $0.01 \mathrm{~N} \mathrm{HCl}$ (Sigma-Aldrich, St. Louis, MO, USA). The lower chamber was filled with $700 \mu \mathrm{l}$ RPMI-1640 medium (Invitrogen; Thermo Fisher Scientific, Inc.) with $15 \%$ FCS. Following a 48 -h incubation in a $5 \%$ $\mathrm{CO}_{2}$ incubator at $37^{\circ} \mathrm{C}$, membranes were removed. Cells remaining on the upper side of the membranes were wiped off using cotton swabs, while cells that had migrated to the lower chamber were fixed with $500 \mu \mathrm{l}$ methanol for $10 \mathrm{~min}$ at $-20^{\circ} \mathrm{C}$ and stained with $200 \mu 10.1 \%$ crystal violet for $30 \mathrm{~min}$ at $37^{\circ} \mathrm{C}$. Images of five separate fields selected at random (magnification, $\mathrm{x} 100$ ) were captured from each well and the number of migrated cells was counted. The mean number of migrated cells per field was calculated for each experimental condition.

Cell adhesion and proliferation assay. Flat-bottom culture plates (96-well) were coated with $60 \mu 1$ of Matrigel diluted 1:5 in serum-free EpiLife ${ }^{\circledR}$ medium, incubated in $5 \% \mathrm{CO}_{2}$ at $37^{\circ} \mathrm{C}$ for $4 \mathrm{~h}$. NC, blank and LV-treated cells were harvested with $1 \mathrm{ml}$ trypsin-EDTA solution $48 \mathrm{~h}$ following LV infection, washed twice with PBS and resuspended in EpiLife ${ }^{\circledR}$ medium. Cells were added to the coated 96-well plates $\left(5 \times 10^{4}\right.$ cells/well) in quintuplicate and incubated at $37^{\circ} \mathrm{C}$ for $3 \mathrm{~h}$. Subsequently, the 96 -well plates were washed twice with PBS to remove unbound cells and $100 \mu \mathrm{l}$ fresh medium was then added to each well. The remaining adhesive cells in the plate were assessed using a Cell Counting kit (CCK)-8 (Dojindo Molecular Technologies, Inc., Kumamoto, Japan) according to the manufacturer's instructions. Finally, 96-well plates were examined at $450 \mathrm{~nm}$ using a plate reader $2.5 \mathrm{~h}$ later. The results were calculated with the following formula: Adhesion rate $=[$ mean optical density (OD) of treated cells $] /$ (mean OD of corresponding control)x 100 .

In addition, the cell proliferation assay was performed with the CCK-8 (13). Cells were seeded in 96-well plates at $\sim 5 \times 10^{3}$ cells/well and cultured in EpiLife ${ }^{\circledR}$ medium at $37^{\circ} \mathrm{C}$. At the indicated time points $(0,24,48,72$ and $96 \mathrm{~h}), 10 \mu \mathrm{l}$ CCK-8 solution was added to each well and incubated for $2.5 \mathrm{~h}$, followed by examination at $450 \mathrm{~nm}$ using a microplate reader (Bio-Rad Laboratories, Inc., Hercules, CA, USA.).

Cell apoptosis assays. A total of $72 \mathrm{~h}$ following LV infection, cells were harvested with EDTA free-trypsin for apoptosis analysis or passaged and cultured at a density of $5 \times 10^{5}$ cells $/ \mathrm{ml}$ in a 6-well plate for $48 \mathrm{~h}$ prior to apoptosis analysis. Analysis was performed using an annexin V-phycoerythrin (PE)/7-aminoactinomycin D (7-AAD) apoptosis detection kit (BD Biosciences) according to the manufacturer's instructions (14). Briefly, following washing twice with cold PBS and centrifugation at $300 \mathrm{x}$ g for $5 \mathrm{~min}$ at $4^{\circ} \mathrm{C}$, the cells were resuspended in $50 \mu \mathrm{l}$ binding buffer and $5 \mu \mathrm{l}$ 7-AAD for $15 \mathrm{~min}$ at room temperature in the dark. Cells were then incubated with $450 \mu \mathrm{l}$ binding buffer and $1 \mu \mathrm{l}$ annexin V-PE for $15 \mathrm{~min}$ in the dark and detected immediately on a FACSCalibur flow cytometer (BD Biosciences) using CellQuest software version 3.2 (BD Biosciences).

Cell cycle analysis. Following LV infection, cells were incubated at a density of $5 \times 10^{5}$ cells $/ \mathrm{ml}$ in a 6 -well plate for $48 \mathrm{~h}$. Cells $\left(1-5 \times 10^{6}\right.$ cells $\left./ \mathrm{ml}\right)$ were then washed twice with ice-cold PBS, resuspended in $500 \mu \mathrm{l}$ PBS and fixed with $1.5 \mathrm{ml}$ of precooled $100 \%$ ethanol overnight at $4^{\circ} \mathrm{C}$. Following two PBS washes, the fixed cells were centrifuged $(300 \mathrm{x} \mathrm{g}$, $5 \mathrm{~min}, 4^{\circ} \mathrm{C}$ ) to remove the ethanol. Cells were adjusted to $1-10 \times 10^{5}$ cells $/ \mathrm{ml}$ and incubated with $150 \mu 1$ RNaseA $(250-500 \mu \mathrm{g} / \mathrm{ml})$ for $30 \mathrm{~min}$ at $37^{\circ} \mathrm{C}$, followed by the addition of $100 \mu \mathrm{l}$ propidium iodide (Sigma-Aldrich) for $30 \mathrm{~min}$ at $4^{\circ} \mathrm{C}$ in the dark. DNA content was analyzed using a FACSCalibur flow cytometer at an excitation wavelength of $488 \mathrm{~nm}$ (15).

Western blotting. Cells were harvested $72 \mathrm{~h}$ following LV infection and washed twice with ice-cold PBS. Briefly, the cells were lysed and homogenized with radioimmunoprecipitation assay lysis buffer (Thermo Fisher Scientific, Inc.) for $30 \mathrm{~min}$ on ice. Samples were diluted with 2X SDS-PAGE loading buffer $(1: 1)$, followed by thermal denaturation at $100^{\circ} \mathrm{C}$ for $5 \mathrm{~min}$. Following cooling, the supernatants were collected by centrifugation at $10,000 \mathrm{x} \mathrm{g}$ at $4^{\circ} \mathrm{C}$ for $10 \mathrm{~min}$. The protein concentration was quantified by a bicinchoninic acid assay (Pierce; Thermo Fisher Scientific, Inc.) according to the manufacturer's instructions. Protein samples $(30 \mathrm{mg})$ were separated using a 10\% SDS-PAGE gel $(100 \mathrm{mV})$, and transferred to nitrocellulose membranes. Following blocking with 5\% nonfat milk in Tris-buffered saline and Tween 20 (TBST) for $2 \mathrm{~h}$, the membranes were incubated overnight at $4{ }^{\circ} \mathrm{C}$ with primary antibodies: Rabbit anti-filaggrin monoclonal antibody (catalog no. PRB-417P; 1:250) purchased from Covance, Inc. (Princeton, NJ, USA) and 

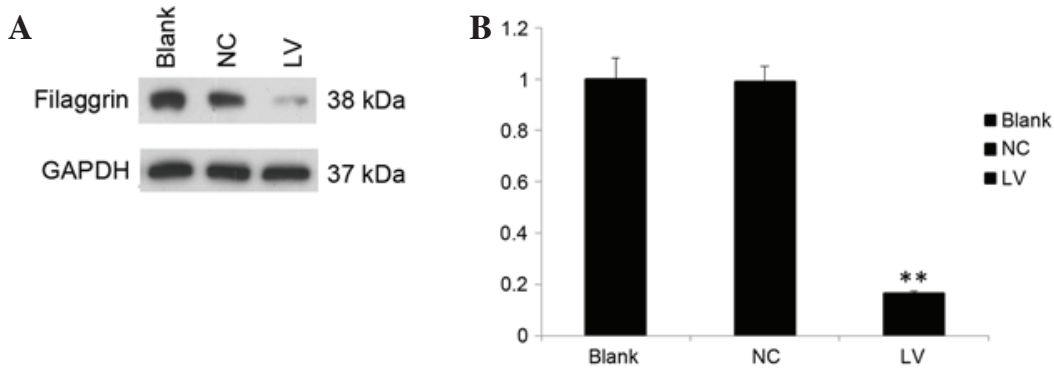

Figure 1. Filaggrin knockdown in NHEKs. (A) Western blot analysis of filaggrin protein expression levels in NHEKs. Cells were infected with LV encoding shRNA targeting filaggrin (LV group), LV encoding nonsense shRNA (NC group) or uninfected (blank group). Filaggrin protein expression levels were determined $72 \mathrm{~h}$ following LV infection, with GADPH serving as the internal reference. (B) Quantification of western blot analysis. The expression level of filaggrin protein was significantly inhibited. ${ }^{* *} \mathrm{P}<0.01$ vs. NC group. NHEKs, normal human epidermal keratinocytes; LV, lentivirus; $\mathrm{NC}$, negative control.
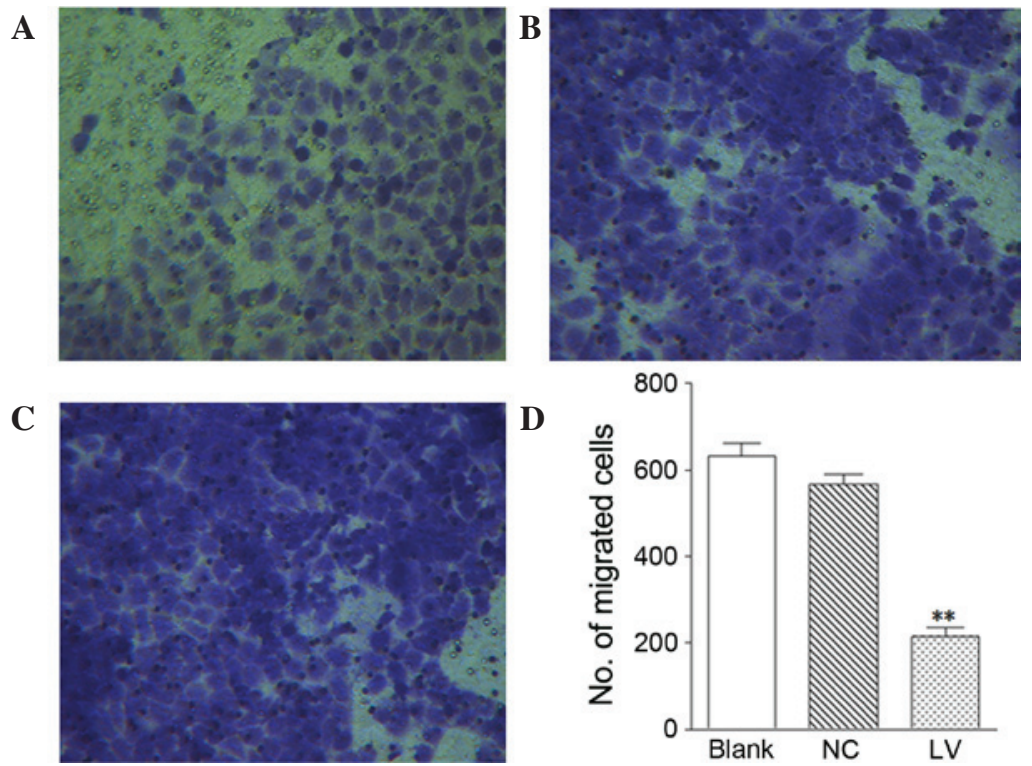

Figure 2. Effect of filaggrin knockdown on migration and invasion of NHEKs. Transwell inserts were used to investigate the migration of NHEKs. Following incubation, cells that had migrated to the lower chamber were stained and analyzed. Images of migrated NHEKs in the (A) LV, (B) NC and (C) blank groups are presented. (D) The number of migrated NHEKs was counted in five random fields in the LV, NC and blank groups, and presented as the mean \pm standard deviation. The number of migrated NHEKs in the LV group was significantly reduced compared with the NC and blank groups ( $\left({ }^{* *} \mathrm{P}<0.01 \mathrm{vs.} \mathrm{the} \mathrm{NC} \mathrm{group).}\right.$ Magnifications, x100. NHEKs, normal human epidermal keratinocytes; LV, lentivirus; NC, negative control.

rabbit anti-GAPDH antibody (catalog no. sc-25778; 1:3,000) purchased from Santa Cruz Biotechnology, Inc. Membranes were washed with TBST three times and incubated with a goat-rabbit IgG secondary antibody conjugated to horseradish peroxidase (catalog no. sc-2030; 1:1,000) purchased from Santa Cruz Biotechnology, Inc. Reactive bands were detected by enhanced chemiluminescence reagent (Pierce; Thermo Fisher Scientific, Inc.). Protein expression levels were quantified using Gel-Pro Analyzer software version 3.1 (Media Cybernetics, Inc., Rockville, MD, USA). GAPDH served as the internal reference.

Statistical analysis. Data are presented as the mean \pm standard deviation, and all statistical analyses were conducted using SPSS version 13.0 (SPSS, Inc., Chicago, IL, USA). Differences between the experimental groups were analyzed using Student's $t$-test, or one-way analysis of variance followed by the least significant difference post hoc test. $\mathrm{P}<0.05$ was considered to indicate a statistically significant difference.

\section{Results}

shRNA infection effectively knocks down filaggrin expression levels. The effect of shRNA infection on the protein expression levels of filaggrin was determined by western blotting. As presented in Fig. 1, shRNA infection resulted in a significant decrease in filaggrin protein expression levels at $72 \mathrm{~h}(\mathrm{P}=0.008$ vs. NC group). The results of the present study indicated that filaggrin was successfully knocked down.

Filaggrin knockdown inhibits cell migration. The impact of filaggrin knockdown on cell migration was investigated using Transwell inserts. As presented in (Fig. 2A-D), the LV group (Fig. 2A) had significantly less migrated cells than the NC (Fig. 2B; $\mathrm{P}=0.0059$ ) and blank groups (Fig. 2C). This observation suggested that a lack of filaggrin may markedly inhibit the migration of NHEKs.

Filaggrin knockdown suppresses cell adhesion and proliferation. In addition to cell migration and invasion, the role of 
A

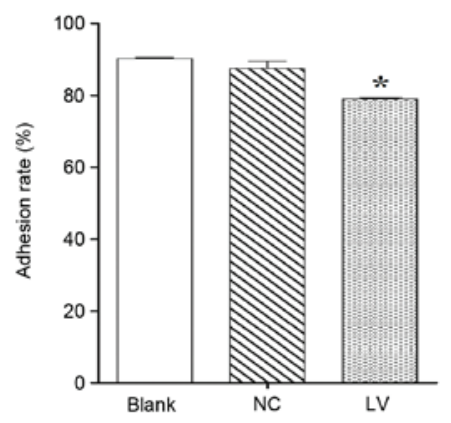

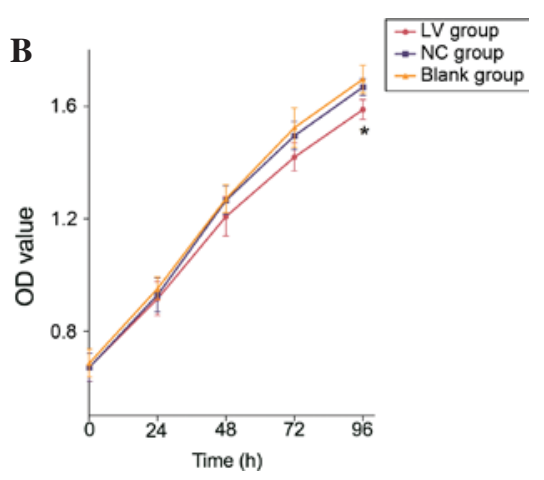

Figure 3. Effect of filaggrin knockdown on adhesion and proliferation of NHEKs. NHEK cells were infected with LV encoding filaggrin shRNA (LV), nonsense shRNA (NC) or uninfected (blank), following which adhesion and proliferation were analyzed using a Cell Counting kit-8. (A) The LV group exhibited decreased cell adhesion compared with the NC and blank groups. Adhesion rate $=($ mean OD of treated cells)/(mean OD of corresponding control)x 100 . (B) The OD values of NHEK cells at $0,24,48,72$ and $96 \mathrm{~h}$ following infection. " $\mathrm{P}<0.05$ vs. NC group. NHEKs, normal human epidermal keratinocytes; LV, lentivirus; NC, negative control; OD, optical density.

A

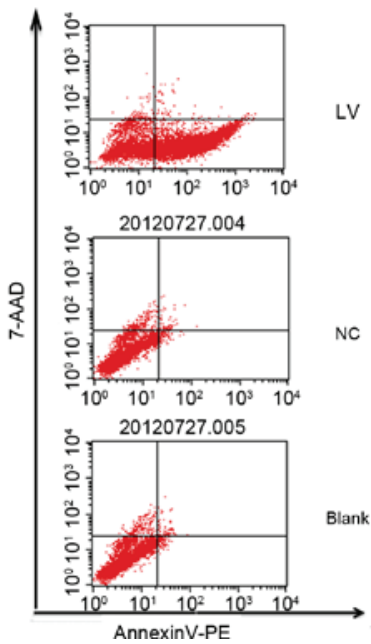

B

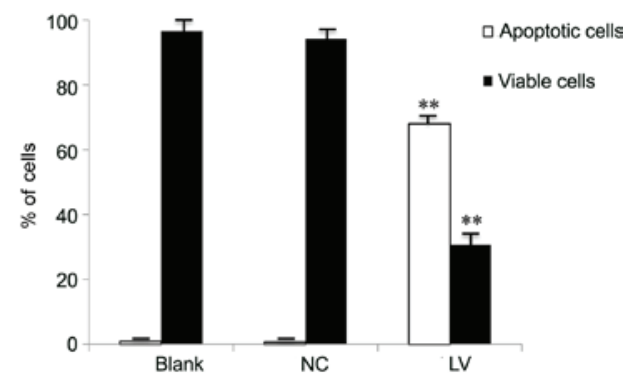

Figure 4. Impact of filaggrin knockdown on apoptosis of NHEKs (72 h following LV infection). (A) Apoptosis analysis of LV, NC and blank groups by flow cytometry. Representative plots of annexin V-PE/7-AAD staining are presented. The population staining positive for annexin $\mathrm{V}$ and negative for 7-AAD (lower right quadrant) was defined as apoptotic. (B) The statistical results of the proportion of apoptotic and viable (lower left quadrant) cells in LV, NC and Blank groups $72 \mathrm{~h}$ following infection. ${ }^{* *} \mathrm{P}<0.01$ vs. NC group. NHEKs, normal human epidermal keratinocytes; LV, lentivirus; NC, negative control; 7-AAD, 7-aminoactinomycin D; PE, phycoerythrin.

filaggrin in cell adhesion and proliferation was analyzed. As presented in Fig. 3A, adhesion of the LV group was significantly inhibited compared with the $\mathrm{NC}(\mathrm{P}=0.023)$ and blank groups. Furthermore, filaggrin knockdown had no significant influence on cell proliferation at $72 \mathrm{~h}$; however, a significant decrease was observed at $96 \mathrm{~h}$ in the $\mathrm{LV}$ group compared with the $\mathrm{NC}(\mathrm{P}=0.034)$ and blank groups (Fig. 3B).

Filaggrin knockdown induces apoptosis. An annexin $\mathrm{V}-\mathrm{PE} / 7-\mathrm{AAD}$ apoptosis detection kit was used to determine the effect of filaggrin knockdown on apoptosis. As presented in Fig. 4, the proportion of early apoptotic cells was significantly increased in the LV group compared with the NC and blank groups (68.01 vs. 0.76 and $0.92 \%$, respectively; $\mathrm{P}=0.0065$ vs. $\mathrm{NC}$ group), while the proportion of viable cells was significantly decreased (30.60 vs. 94.00 and $96.6 \%$; $\mathrm{P}=0.0063$ vs. $\mathrm{NC}$ group), at $72 \mathrm{~h}$ following infection. Passaged cells ( $72 \mathrm{~h}$ following infection and $48 \mathrm{~h}$ following passage), exhibited a similarly significant increase in the percentage of early apoptotic cells (72.14 vs. 0.56 and $0.82 \% ; \mathrm{P}=0.0054$ vs. NC group) and a significant decrease in the proportion of viable cells ( 25.88 vs. 94.22 and $95.23 \%$; $\mathrm{P}=0.0076$ vs. $\mathrm{NC}$ group; Fig. 5). Therefore, filaggrin knockdown appeared to induce apoptosis of NHEKs.

Filaggrin knockdown alters cell cycle progression. Flow cytometry was performed to evaluate the effect of filaggrin knockdown on cell cycle progression in NHEKs. As presented in Fig. 6A-C, the cell cycle distribution pattern of the LV group was distinct to that of the NC and blank groups. The proportion of cells in $\mathrm{S}$ phase was significantly reduced ( 18.19 vs. 25.90 and $26.07 \% ; \mathrm{P}=0.034$ vs. $\mathrm{NC}$ group); however, the proportion of cells in $G_{1}$ and $G_{2}$ phases was significantly increased in the LV group compared with the $\mathrm{NC}$ and Blank groups (71.82 vs. 65.29 and $66.25 \% ; \mathrm{P}=0.031$ vs. NC group; and 3.47 vs. 7.92 and $6.89 \% ; \mathrm{P}=0.0064$ vs. NC groups). The increase in cells that had undergone filaggrin knockdown in $\mathrm{G}_{1}$ and $\mathrm{G}_{2}$ stages suggested that $\mathrm{G}_{1} / \mathrm{S}$ transition was inhibited and $\mathrm{S} / \mathrm{G}_{2}$ transition accelerated as a result of filaggrin knockdown. 


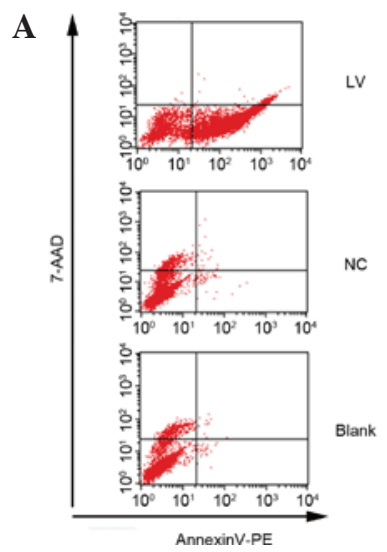

B

Figure 5. Impact of filaggrin knockdown on apoptosis of NHEKs (72 h following infection and $48 \mathrm{~h}$ following passage). (A) Apoptosis analysis of LV, NC and blank groups by flow cytometry. Representative plots of annexin V-PE/7-AAD staining are presented. The population staining positive for annexin $\mathrm{V}$ and negative for 7-AAD (lower right quadrant) was defined as apoptotic. (B) Quantification of the proportion of apoptotic and viable (lower left quadrant) cells in the $\mathrm{LV}, \mathrm{NC}$ and blank groups $72 \mathrm{~h}$ following infection and $48 \mathrm{~h}$ following passage. ${ }^{* *} \mathrm{P}<0.01 \mathrm{vs.} \mathrm{NC} \mathrm{group.} \mathrm{NHEKs,} \mathrm{normal} \mathrm{human} \mathrm{epidermal} \mathrm{keratinocytes;}$ LV, lentivirus; NC negative control; 7-AAD, 7-aminoactinomycin D; PE, phycoerythrin.

$\mathbf{A}$

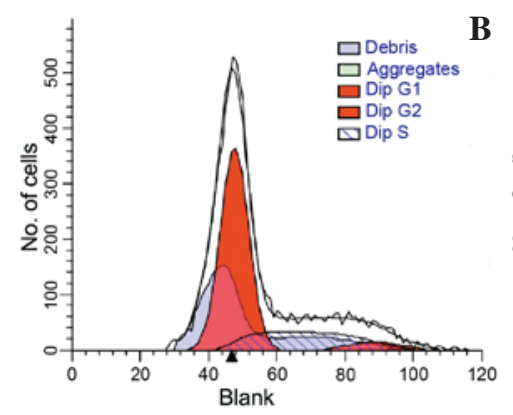

C

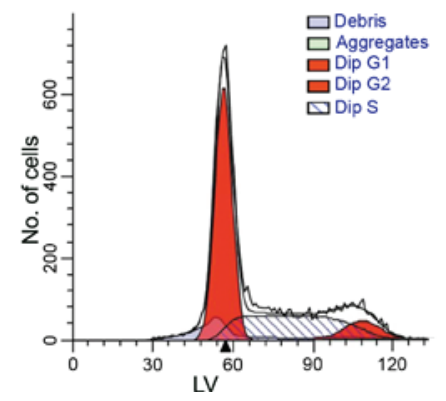

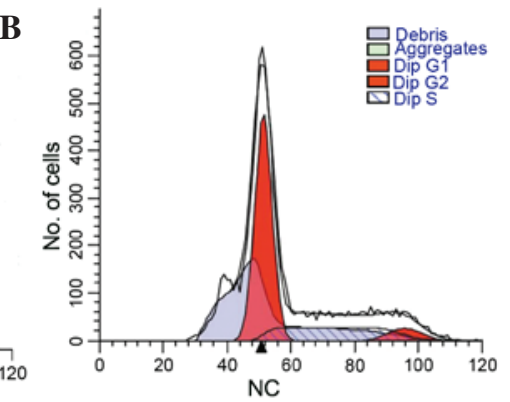

D

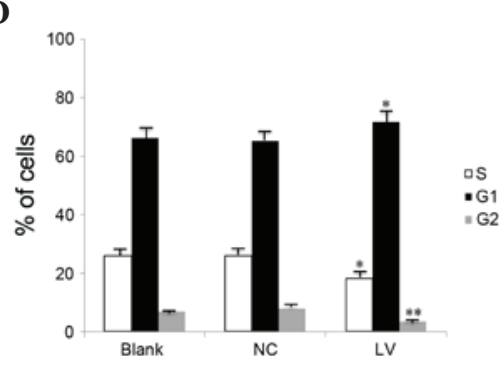

Figure 6. Effect of filaggrin knockdown on the cell cycle of NHEKs (72 h following LV infection). Cell cycle analysis of NHEKs in (A) LV, (B) NC and

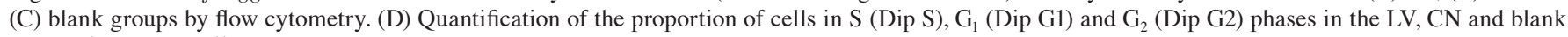
groups. ${ }^{\mathrm{P}}<0.05$ and ${ }^{* *} \mathrm{P}<0.01$ vs. NC group. NHEKs, normal human epidermal keratinocytes; LV, lentivirus; NC, negative control.

\section{Discussion}

Filaggrin mutations may contribute to various diseases, including dry skin, ichthyosis vulgaris, atopic eczema and atopic dermatitis (16). Filaggrin is crucial for epidermal homeostasis and differentiation, and skin barrier function (17). The present study aimed to investigate the effects of filaggrin knockdown on various functions of NHEKs, including cell migration, invasion, adhesion, proliferation, apoptosis and cell cycle progression. Filaggrin was successfully knocked down in NHEKs by infection with LV encoding shRNA of filaggrin, resulting in inhibition of cell migration, adhesion and proliferation, promotion of apoptosis, and disturbance of cell cycle progression.

Cell migration is a highly integrated multistep process, which contributes to tissue formation, regeneration and remodeling, wound healing, and the immune response (18). Tissue repair, regeneration and remodeling require active cell motility, which is also reliant on cell adhesion (19). In addition, cell adhesion is involved in the maintenance of multicellular structures, signal transduction and cancer metastasis (20). Cell migration and adhesion are closely associated with terminal differentiation and epidermal homeostasis $(21,22)$. Our previous study demonstrated that filaggrin knockdown inhibits expression of epidermal differentiation-associated proteins (23). Consistent with these findings, the present study revealed suppression of NHEK migration and adhesion as a result of filaggrin knockdown. Therefore, the absence of filaggrin may prohibit epidermal differentiation by suppressing the migration and adhesion of NHEKs. 
Furthermore, Filaggrin knockdown inhibited cell proliferation and promoted apoptosis. Cell proliferation and apoptosis are involved in epidermal homeostasis and skin wound repair $(21,24)$. These observations indicated that the absence of filaggrin may deregulate epidermal homeostasis and delay wound healing by inhibiting NHEK migration, adhesion and proliferation, and promoting NHEK apoptosis.

Cell cycle progression in the present study was also altered by filaggrin knockdown, as indicated by the increased proportions of cells in $\mathrm{G}_{1}$ and $\mathrm{G}_{2}$ phases, and the reduced proportions of cells in $\mathrm{S}$ phase. Therefore, filaggrin absence slowed down $\mathrm{G}_{1} / \mathrm{S}$ transition and accelerated $\mathrm{S} / \mathrm{G}_{2}$ transition, which may provide an explanation for the inhibition of proliferation by filaggrin knockdown. These results suggest that filaggrin is involved in the regulation of cell cycle progression; however, further studies are required to validate this effect.

Evidence suggests that the MAPK and phosphoinositide 3-kinase/Akt signaling pathways are involved in regulating keratinocyte differentiation, proliferation and apoptosis (25-28). Downregulation of Akt has been reported to promote apoptosis, and inhibit cell migration and proliferation (29). Activation of Akt reverses cell cycle arrest in $\mathrm{G}_{1}$ and $\mathrm{G}_{2}$ phases in response to DNA injury (30). Furthermore, the effect of Akt on cellular survival and metabolism is mediated by binding to downstream NF- $\mathrm{B}$ (31). Filaggrin absence may inhibit the differentiation of NHEKs by suppressing phosphorylation of P38, ERK1/2, JNK, Akt and $\mathrm{NF}-\kappa \mathrm{B}$. Therefore, filaggrin knockdown may inhibit cell migration, adhesion and proliferation, promote cell apoptosis and disturb cell cycle progression via suppression of these signaling pathways. However, further experiments are required to confirm this hypothesis.

In conclusion, the results of the present study demonstrate that filaggrin knockdown inhibits NHEK migration, adhesion and proliferation, promotes apoptosis and disturbs cell cycle progression. These findings contribute to the understanding of the role of filaggrin in epidermal keratinocytes, and may facilitate the determination of the pathogenesis of filaggrin mutation-associated disorders.

\section{Acknowledgements}

The present study was supported by the China Postdoctoral Science Foundation (grant nos. 2014M550370 and 2015T80740).

\section{References}

1. McGrath JA and Uitto J: The filaggrin story: Novel insights into skin-barrier function and disease. Trends Mol Med 14: 20-27, 2008.

2. Ovaere P, Lippens S, Vandenabeele P and Declercq W: The emerging roles of serine protease cascades in the epidermis. Trends Biochem Sci 34: 453-463, 2009.

3. Levin J, Friedlander SF and Del Rosso JQ: Atopic dermatitis and the stratum corneum: Part 1: The role of filaggrin in the stratum corneum barrier and atopic skin. J Clini Aesthet Dermatol 6: 16-22, 2013.

4. Sandilands A, Sutherland C, Irvine AD and McLean WH: Filaggrin in the frontline: Role in skin barrier function and disease. J Cell Sci 122: 1285-1294, 2009.

5. Weidinger S, Illig T, Baurecht $\mathrm{H}$, Irvine AD, Rodriguez E, Diaz-Lacava A, Klopp N, Wagenpfeil S, Zhao Y, Liao H, et al: Loss-of-function variations within the filaggrin gene predispose for atopic dermatitis with allergic sensitizations. J Allergy Clin Immunol 118: 214-219, 2006.
6. O'Regan GM, Sandilands A, McLean WH and Irvine AD: Filaggrin in atopic dermatitis. J Allergy Clin Immunol 124 (3 Suppl 2): R2-R6, 2009.

7. Sun LD, Xiao FL, Li Y, Zhou WM, Tang HY, Tang XF, Zhang H, Schaarschmidt H, Zuo XB, Foelster-Holst R, et al: Genome-wide association study identifies two new susceptibility loci for atopic dermatitis in the Chinese Han population. Nat Genet 43: 690-694, 2011.

8. Presland RB, Kuechle MK, Lewis SP, Fleckman P and Dale BA: Regulated expression of human filaggrin in keratinocytes results in cytoskeletal disruption, loss of cell-cell adhesion, and cell cycle arrest. Exp Cell Res 270: 199-213, 2001.

9. Kuechle MK, Presland RB, Lewis SP, Fleckman P and Dale BA: Inducible expression of filaggrin increases keratinocyte susceptibility to apoptotic cell death. Cell Death Differ 7: 566-573, 2000.

10. Ishida-Yamamoto A, Tanaka H, Nakane H, Takahashi $H$, Hashimoto Y and Iizuka H: Programmed cell death in normal epidermis and loricrin keratoderma. Multiple functions of profilaggrin in keratinization. J Investig Dermatol Symp Proc 4: 145-149, 1999.

11. Zhang J, Shan L, Koussih L, Redhu NS, Halayko AJ, Chakir J and Gounni AS: Pentraxin 3 (PTX3) expression in allergic asthmatic airways: Role in airway smooth muscle migration and chemokine production. PLoS One 7: e34965, 2012.

12. Kramer N, Walzl A, Unger C, Rosner M, Krupitza G, Hengstschläger $\mathrm{M}$ and Dolznig $\mathrm{H}$ : In vitro cell migration and invasion assays. Mutat Res 752: 10-24, 2013.

13. Kong X, Chang X, Cheng H, Ma R, Ye X and Cui H: Human epididymis protein 4 inhibits proliferation of human ovarian cancer cells via the mitogen-activated protein kinase and phosphoinositide 3-kinase/AKT pathways. Int J Gynecol Cancer 24: 427-436, 2014.

14. Xu QF, Pan YW, Li LC, Zhou Z, Huang QL, Pang JC, Zhu XP, Ren Y, Yang H, Ohgaki H and Lv SQ: MiR-22 is frequently downregulated in medulloblastomas and inhibits cell proliferation via the novel target PAPST1. Brain Pathol 24: 568-583, 2014.

15. Choi YK, Seo HS, Choi HS, Choi HS, Kim SR, Shin YC and Ko SG: Induction of Fas-mediated extrinsic apoptosis, p21WAF1-related G2/M cell cycle arrest and ROS generation by costunolide in estrogen receptor-negative breast cancer cells, MDA-MB-231. Mol Cell Biochem 363: 119-128, 2012.

16. Thyssen JP, Ross-Hansen K, Johansen JD, Zachariae C, Carlsen BC, Linneberg A, Bisgaard H, Carson CG, Nielsen NH, Meldgaard M, et al: Filaggrin loss-of-function mutation R501X and 2282del4 carrier status is associated with fissured skin on the hands: Results from a cross-sectional population study. Br J Dermatol 166: 46-53, 2012.

17. McAleer MA and Irvine AD: The multifunctional role of filaggrin in allergic skin disease. J Allergy Clin Immunol 131: 280-291, 2013.

18. Ridley AJ, Schwartz MA, Burridge K, Firtel RA, Ginsberg MH, Borisy G, Parsons JT and Horwitz AR: Cell migration: Integrating signals from front to back. Science 302: 1704-1709, 2003.

19. Griffith LG and Naughton G: Tissue engineering-current challenges and expanding opportunities. Science 295: 1009-1014, 2002.

20. Gumbiner BM: Cell adhesion: The molecular basis of tissue architecture and morphogenesis. Cell 84: 345-357, 1996.

21. Livshits G, Kobielak A and Fuchs E: Governing epidermal homeostasis by coupling cell-cell adhesion to integrin and growth factor signaling, proliferation, and apoptosis. Proc Natl Acad Sci USA 109: 4886-4891, 2012.

22. Amelio I, Lena AM, Viticchiè G, Shalom-Feuerstein R, Terrinoni A, Dinsdale D, Russo G, Fortunato C, Bonanno E, Spagnoli LG, et al: miR-24 triggers epidermal differentiation by controlling actin adhesion and cell migration. J Cell Biol 199: 347-363, 2012.

23. Dang NN, Pang SG, Song HY, An LG and Ma XL: Filaggrin silencing by shRNA directly impairs the skin barrier function of normal human epidermal keratinocytes and then induces an immune response. Braz J Med Biol Res 48: 39-45, 2015.

24. Lewis CJ, Mardaryev AN, Poterlowicz K, Sharova TY, Aziz A, Sharpe DT, Botchkareva NV and Sharov AA: Bone morphogenetic protein signaling suppresses wound-induced skin repair by inhibiting keratinocyte proliferation and migration. J Invest Dermatol 134: 827-837, 2014.

25. Popp T, Egea V, Kehe K, Steinritz D, Schmidt A, Jochum M and Ries C: Sulfur mustard induces differentiation in human primary keratinocytes: Opposite roles of p38 and ERK1/2 MAPK. Toxicol Lett 204: 43-51, 2011. 
26. Efimova T, Broome AM and Eckert RL: A regulatory role for p38 delta MAPK in keratinocyte differentiation. Evidence for p38 delta-ERK1/2 complex formation. J Bioll Chem 278: 34277-34285, 2003

27. Jonak C, Mildner M, Klosner G, Paulitschke V, Kunstfeld R, Pehamberger H, Tschachler E and Trautinger F: The hsp27kD heat shock protein and $\mathrm{p} 38$-MAPK signaling are required for regular epidermal differentiation. J Dermatol Sci 61: 32-37, 2011

28. Calautti E, Li J, Saoncella S, Brissette JL and Goetinck PF: Phosphoinositide 3-kinase signaling to Akt promotes keratinocyte differentiation versus death. J Bioll Chem 280: 32856-32865, 2005.
29. Pap M and Cooper GM: Role of glycogen synthase kinase-3 in the phosphatidylinositol 3-kinase/Akt cell survival pathway. J Bioll Chem 273: 19929-19932, 1998

30. Kandel ES, Skeen J, Majewski N, Di Cristofano A, Pandolfi PP, Feliciano CS, Gartel A and Hay N: Activation of Akt/protein kinase B overcomes a $\mathrm{G}(2) / \mathrm{M}$ cell cycle checkpoint induced by DNA damage. Mol Cell Biol 22: 7831-7841, 2002.

31. Faissner A, Heck N, Dobbertin A and Garwood J: DSD-1-Proteoglycan/Phosphacan and receptor protein tyrosine phosphatase-beta isoforms during development and regeneration of neural tissues. Adv Exp Med Biol 557: 25-53, 2006. 